AGRO EKONOMI, Vol 29, Issue 2, December 2018, Page. 335-345

DOI : http://doi.org/10.22146/ae.35786

ISSN 0215-8787 (print), ISSN 2541-1616 (online)

Available at https://jurnal.ugm.ac.id/jae/

\title{
THE IMPACT OF GOOD AGRICULTURE PRACTICES (GAP) IMPLEMENTATION ON PRODUCTIVITY OF PACIFIC WHITE SHRIMP IN GRABAG DISTRICT PURWEREJO REGENCY
}

\section{Pengaruh Penerapan Good Agriculture Practices (GAP)Terhadap Produktivitas Udang Vaname di Kecamatan Grabag Kabupaten Purworejo}

\author{
Asyifa Anandya ${ }^{1}{ }^{1}$ Jamhari $^{2}$, Suhatmini Hardyastuti ${ }^{3}$ \\ ${ }^{1}$ PSDKU Universitas Brawijaya Kediri \\ ${ }^{2,3}$ Faculty of Agriculture, Universitas Gadjah Mada \\ ${ }^{1} \mathrm{Jl}$. Sersan Bachrun, Mrican, Mojoroto, Kediri \\ ${ }^{2,3} \mathrm{~J}$ l. Flora No. 1 Bulaksumur, Yogyakarta \\ asyifaanandya@yahoo.com
}

Submitted: 29 May 2018; Revised: 26 July 2018; Accepted: 13 December 2018

\begin{abstract}
Purworejo Regency is one of the centers of pacific white shrimp farming in Indonesia. One of the sub-districts in Purworejo Regency which successfully breeds the pacific white shrimp is Grabag Sub District. It won the first place of shrimp cultivation competition inorganization and institution performace assessment category for Central Java Province level. Not to mention, it achieved the first place winner in shrimp cultivation category at national level. This research was located in the sub district of Grabag, Purworejo regency on October December 2017. The aims of this research are to determine the effect of human capital on the GAP implementation by the farmers and the effect of the GAP implementation on pacific white shrimp productivity. The number of respondents in this research was 75 farmers which were chosen by purposive sampling. This research used regression analysis with Two Stage Least Square model. The results of this research showed that (1) The GAP implementation was influenced by the level of education and farmers' experiences, while there was no effect influenced by the age on the GAP implementation, and (2) The GAP implementation of pacific white shrimp cultivation did not affect the pacific white shrimp productivity. However, the GAP implementation did not contradict the productivity. The environmentally friendly GAP implementation and quality oriented approach did not contradict the productivity of shrimp. Farmers still can implement the GAP without decreasing their productivity.
\end{abstract}

Keywords : GAP, human capital, pacific white shrimp, productivity

Anandya, A., Jamhari, \& Hardyastuti, S. (2018) The Impact of Good Agriculture Practices (GAP) Implementation on Productivity of Pacific White Shrimp in Grabag District Purwerejo Regency. Agro Ekonomi, 29(2) : 335-345

\section{INTISARI}

Kabupaten Purworejo merupakan salah satu sentra budidaya udang vaname di Indonesia. Salah satu daerah di Kabupaten Purworejo yang sukses melakukan budidaya udang vaname 
ialah Kecamatan Grabag, di mana pernah meraih juara I Kategori Pembudidayaan Udang pada Penilaian Kinerja Kelompok dan Kelembagaan Bidang Perikanan Budidaya Tingkat Provinsi Jawa Tengah dan Juara I Nasional dalam Kategori Budidaya Udang. Penelitian ini dilaksanakan di Kecamatan Grabag Kabupaten Purworejo pada bulan Oktober sampai Desember 2017. Tujuan dari penelitian ini untuk mengetahui pengaruh human capital terhadap penerapan GAP oleh petambak dan mengetahui pengaruh penerapan GAP terhadap produktivitas udang vaname. Jumlah responden dalam penelitian ini sebanyak 75 orang petambak yang diambil dengan purposive sampling. Penelitian ini menggunakan analisis regresi dengan model Two Stage Least Square. Hasil analisis menunjukkan bahwa (1) penerapan GAP dipengaruhi oleh pendidikan dan pengalaman petambak, sedangkan umur tidak berpengaruh terhadap penerapan GAP dan (2) penerapan GAP budidaya udang vaname tidak mempengaruhi produktivitas udang vaname, namun penerapan GAP tidak bertentangan dengan produktivitas.Penerapan GAP yang ramah lingkungan dan mengutamakan mutu udang yang dihasilkan tidak bertentangan untuk menghasilkan produktivitas udang yang tinggi. Petambak tetap dapat menerapkan GAP tanpa mengalami penurunan produktivitas.

Kata kunci: GAP, human capital, GAP, udang vaname, produktivitas

\section{INTRODUCTION}

The ministry of Maritime Affairs and Fisheries for the period of 2009-2014, explains that one of the main concerns is to increase the domestic fishery productivity. The vision is to realize that Indonesia is the largest producer of marine and fishery product in 2015, while the mission is to prosper the marine and fishery society. Therefore, there should be an enhancement of fishery production in Indonesia by increasing more production on land fishery cultivation business. One of shrimp revitalisation programme in 2005 was switching land area for asian tiger shrimp into land area for pacific white shrimp. The presence of pacific white shrimp is expected to make shrimp aquaculture investment interesting (Andriyanto et al., 2013). Grabag Sub District in Purworejo Regency is one of the pacific white shrimp production area in Indonesia. It is the winner in good pacific white shrimp cultivation category.

Haliman and Adijaya (2005), quoted by (Arsad et al., 2017), stated that to produce pacific white shrimp with good quality, the maintenance process should consider some internal aspects by involving the origin and quality of seeds. While the external factors involves the quality of water, feeding, technology, and pests and diseases treatment. To handle those factors, Ministry of Maritime Affairs and Fisheries has released a guidelines about how to run an effective pacific white cultivation or any kind of aquaculture, namely Good Agriculture Practices (GAP), through the decision of the Indonesian Ministry of Maritime Affairs and Fisheries number KEP.02/MEN/2007, with the aim of achieving quality assurance and safety of 
national and international fishery products.

That was one of government's efforts to implement the sustainable fisheries by applying GAP technology.

The implementation of the principles of Good Agriculture Practices (GAP) as a manifestation of sustainable agriculture conducted by farmers will certainly vary. It depends on farmers' perceptions and assessments about the positive or negative benefits which are expected by the farmers to produce their yields (Sari et al., 2016).

Variations in technology adoption, a group of farmers should be formed as a learning area. Pacific white shrimp cultivation costs a lot. However, each farmer has different financial capabilities, so the implementation of GAP for each farmer is limited. Personal management leads the group to become the place where the members can learn technology deeply. Furthermore, it can change the member's mindset from unwilling to adopt to be more willing to apply the GAP technology. Variations of human capital, including ages, education, and experience, will affect GAP implementation.

According to the study conducted by Sundari \& Priyanto (2016) on efficiency of production factors utilization on nursery technology of catfish revelaed that land area and labor did not affect production of catfish while seeds and feedsignificantly affected catfish production.

Recently, there has been much research taken place in Purworejo Regency about pacific white shrimp cultivation. None of them did the research about GAP implementation of pacific white shrimp in Purworejo Regency. Several examples of common research of pacific white shrimp cultivation in Purworejo Regency are conducted by Utomo et al.(2012) on the feasibility study of pacific white shrimp cultivation, Suryani(2016) on the ecology feasibility of shrimp cultivation in order to increase food security, and Triyatmo et al.(2016) on the feasibility study on the profitability of vannamei shrimp aquaculture on coastal area.

Due to the development of pacific white shrimp cultivation in Grabag Sub District, it is necessary to do research on the extent of GAP implementation by the farmers. This study aims to determine whether or not the human capital affect GAP implementation, and whether the GAP implementation affect productivity or not. The pacific white shrimp's GAP implementation is divided into eighteen indicators, namely the provision of location, water supply, layout and design, hygiene facility and equipment, preparation of cultivation media, water management, shrimp seed, feed, chemical, biological and fish medicine application, ice and water application, harvest, post-harvest handling, transportation, waste disposal, recording, corrective action, training, and hygiene personil. 


\section{METHODS}

\section{Location and Data}

This research was located in Grabag Sub District, Purworejo Regency. The location was selected purposively, because one of farmer groups in Grabag Sub District won the shrimp cultivation competition in 2015. Samples were taken from five villages in Grabag Sub District, consisting of Harjobinangun Village, Ketawangrejo Village, Patutrejo Village, Kertojayan Village and Munggangsari Village. Data collection was done through primary and secondary sources. The number of respondents used in this research was 75 farmers, chosen by using purposive sampling method.

\section{Analysis of Human Capital Affecting the Level of GAP Implementation}

Two Stage Least Square (2SLS) regression analysis was used to determine how significant the GAP impelementation in Grabag Sub District affecting by human capital. The dependent variables (PGAP) was GAP implementation which was expected to be affected by human capital as independent variables, which were farmers' age (Umr), farmers' education (Pdd), and farmers' experience (Plm). Equation formulas for this model are:

$$
\begin{gathered}
\operatorname{Ln} \text { PGAP }=\mathrm{a}+\mathrm{b} 1 \ln \mathrm{Umr}+\mathrm{b} 2 \ln \mathrm{Pdd}+ \\
\mathrm{b} 3 \ln \mathrm{P} \operatorname{lm}
\end{gathered}
$$

Information:

LnPGAP = GAP Implementation (score)

a

$$
=\text { constants }
$$

$\mathrm{b} 1, \mathrm{~b} 2, \mathrm{~b} 3=$ regression coefficient

LnUmr = farmers' age (year)

LnPdd = farmers' education (year)

LnPlm = farmers' experience (year)

The hypothesis test in this analysis included several tests as follows:

a. Determination coefficient test (Adjusted R $^{2}$ )

b. Simultaneous test (F-test)

c. Individual test (t-test)

\section{Analysis of the Level of GAP Implementation Affecting the \\ Productivity}

To determine the factors, including GAP implementation, which influence the productivity of pacific white shrimp in Grabag Sub District, Two Stage Least Square (2SLS) analysis was used. The dependent variable $(\mathrm{Y})$ was productivity of pacific white shrimp suspected to be the effect of independent variables, which were pond area (LK), shrimp seed (Bnr), feed (Pkn), probiotic (Pro), Labor (HKO), and GAP implementation score (PGAP). Equation formulas for this model are:

$$
\begin{gathered}
\operatorname{Ln} \mathrm{Y}=\mathrm{a}+\mathrm{b} 1 \ln \mathrm{LK}+\mathrm{b} 2 \ln \mathrm{Bnr}+\mathrm{b} 3 \ln \\
\mathrm{Pkn}+\mathrm{b} 4 \ln \mathrm{Pro}+\mathrm{b} 5 \ln (\mathrm{HKO})+\mathrm{b} 6 \ln \\
\text { PGAP }
\end{gathered}
$$

Information:

$\mathrm{Y} \quad=$ productivity of pacific white shrimp $\left(\mathrm{kg} / \mathrm{m}^{2}\right)$

$\mathrm{a}=$ constants

b1, b12, b3, b4, b5, b6 = regression coefficients 
$\mathrm{LK}=$ pond area $\left(\mathrm{m}^{2}\right)$

$\mathrm{Bnr}=\operatorname{shrimp}$ seed $\left(\mathrm{seed} / \mathrm{m}^{2}\right)$

Pkn $=$ feed $\left(\mathrm{kg} / \mathrm{m}^{2}\right)$

Pro $=$ probiotic $\left(\right.$ liter $\left./ \mathrm{m}^{2}\right)$

HKO $=$ labor $\left(\mathrm{hko} / \mathrm{m}^{2}\right)$

$\mathrm{PGAP}=\mathrm{GAP}$ implementation (score)

\section{RESULTS AND DISCUSSION}

In this research, the respondents were grouped into three categories, which were low, moderate, and high level of GAP implementation based on total score in each scope. The number of items which were used to measure the level of GAP implementation is 55 statements, and divided into 18 indicators. Each statement was adjusted to the Regulation of the Minister of Maritime Affairs and Fisheries Number KEP.02/MEN/2007 about good agriculture practices.

Table 1 shows that the total average score for all indicators is 4.01 meaning that the farmers are implementing about $80.20 \%$ of the overall indicators. Meanwhile, there are 4 indicators with low score such as chemical, biological, and fish medicine application, post-harvest handling, recording, and training. The indicator of chemical, biological, and fish medicine application score is low since farmers usually use their own medicines, such as ginger, antidiarrheal medicines for human, and other ingredients which are perceived powerful by farmers to cure the shrimp disease.
Table 1. The Rate of GAP Implementation for Pacific White Shrimp in Grabag Sub District

\begin{tabular}{|c|c|c|}
\hline $\begin{array}{c}\text { Indicators of } \\
\text { Implementation }\end{array}$ & $\begin{array}{c}\text { Average } \\
\text { Score } \\
\end{array}$ & $\begin{array}{c}\text { Percentage } \\
(\%)\end{array}$ \\
\hline Location & 4.67 & 93.40 \\
\hline Water Supply & 4.12 & 82.40 \\
\hline Layout and Design & 4.50 & 90.00 \\
\hline $\begin{array}{l}\text { Hygiene Facility } \\
\text { and Equipment }\end{array}$ & 4.47 & 89.40 \\
\hline $\begin{array}{l}\text { Preparation of } \\
\text { Culture Media }\end{array}$ & 4.38 & 87.60 \\
\hline Water Treatment & 3.98 & 79.60 \\
\hline Shrimp Seed & 4.89 & 97.80 \\
\hline Feed & 4.24 & 84.80 \\
\hline $\begin{array}{l}\text { Chemical, } \\
\text { Biological, and } \\
\text { Fish Medicine } \\
\text { Application }\end{array}$ & 3.33 & \\
\hline $\begin{array}{l}\text { Ice and Water } \\
\text { Application }\end{array}$ & 4.17 & $\begin{array}{l}66.67 \\
83.40\end{array}$ \\
\hline Harvest & 4.34 & 86.80 \\
\hline $\begin{array}{c}\text { Post-harvest } \\
\text { Handling }\end{array}$ & 3.21 & 64.20 \\
\hline Transportation & 4.09 & 81.80 \\
\hline Waste Disposal & 3.65 & 73.00 \\
\hline Recording & 3.42 & 68.40 \\
\hline Corrective Action & 3.65 & 73.00 \\
\hline Training & 3.33 & 66.67 \\
\hline Hygiene Personil & 4.63 & 92.60 \\
\hline Total & 4.01 & 80.20 \\
\hline
\end{tabular}

Source: Analysis of Primary Data (2018)

Then, the indicator of post-harvest handling is low as farmers usually exert chemicals to clean the equipment for handling post-harvest, such as chlorine. Importantly, in GAP, it is not allowed to use any kind of chemicals. Furthermore, the recording indicator is low because farmers usually only record the amount of feed each day and harvest. They do not record the water quality and the disease which attack the shrimp, while those are required to be recorded by farmers in GAP. 
The last indicator with low score is training, because The Department of Agriculture, Food, Marine and Fisheries of Purworejo Regency never conducts training for farmers in Grabag Sub District. Some farmers are trained by a feed company and Jepara Government, while others do not take the training, because they trust more in other farmers who were more successful in pacific white shrimp cultivation rather than the experts in the training.

Not all farmers in Grabag Sub District implement GAP, while there are even some farmers do not know what GAP is. Farmers who know GAP do not necessarily implement it, because they think that it is a new technology so they are afraid to take risks if they implement it. The information about GAP is difficult to be obtained by farmers, because local services never hold training about it. Farmers usually attend the training which held by Jepara Government on their own initiative. However, farmers who implement GAP have their own constraints as well, such as the difficulty of obtaining capital. Because it requires more capital to implement GAP.

Based on table 2, all respondents in Grabag Sub District are in productive age. Most of the farmers are senior high school graduate $(49.43 \%)$, while those who obtain bachelor degree is $21.33 \%$. Farmer's education affects the way of their thinking especially about how they run their farm business. Lower educational level of farmers would cause them to make risky decisions and inhibit their business, so that new agriculture innovations tend to be accepted slowly (Lestari et al., 2009).

Farmer's experiences of farming pacific white shrimp is mostly between 2.13 years $(36.00 \%)$ and $3.1-4$ years $(36.00 \%)$.

Table 2. Characteristics of Respondents

\begin{tabular}{lrcc}
\hline \multicolumn{1}{c}{ Charateristics } & \multicolumn{1}{c}{ Groups } & $\begin{array}{c}\text { Number of } \\
\text { Farmers }\end{array}$ & $\begin{array}{c}\text { Percentage } \\
(\%)\end{array}$ \\
\hline Ages (year) & $\leq 14$ years old & 0 & 0 \\
& $15-64$ years old & 75 & 100 \\
& $\geq 65$ years old & 0 & 0 \\
\hline Education & Elementary school & 7 & 9.33 \\
& Junior high school & 10 & 13.33 \\
& Senior high school & 37 & 49.34 \\
& Diploma degree & 3 & 4.00 \\
& Bachelor degree & 16 & 21.33 \\
& Master degree & 2 & 2.67 \\
\hline Farming experiences (year) & $1-2$ & 11 & 14.67 \\
& $2.1-3$ & 27 & 36.00 \\
& $3.1-4$ & 27 & 36.00 \\
& $4.1-5$ & 9 & 12.00 \\
& $>5$ & 1 & 1.33 \\
\hline
\end{tabular}

Source: Analysis of Primary Data (2018) 
Farmers will solve their problems easier if they have worked for their farm in a long time. They also have more patience when dealing with relevant problems (Lestari et al., 2009).

\section{The Effect of Human Capital to the Level of GAP Implementation}

Table 3. The Result of Analysis of Human Capital Affecting the GAP Implementation

\begin{tabular}{lrrl}
\hline \multicolumn{1}{c}{ Variables } & Coefficient & \multicolumn{1}{c}{ T stat } & Sig t \\
\hline C & 5.262 & 40.995 & 0.000 \\
Ln Umr & -0.251 & -0.742 & 0.460 \\
Ln Pdd & 0.122 & 5.516 & 0.000 \\
Ln Plm & -0.077 & -0.431 & 0.000 \\
\hline R-squared & & 0.573 \\
Adjusted & & 0.555 \\
R-squared & & \multicolumn{2}{c}{1.667} \\
T-Table & & \multicolumn{2}{c}{1.60} \\
\hline
\end{tabular}

Source: Analysis of Primary Data (2018)

\section{Significant Variables}

The level of formal education has an effect on the GAP implementation by the farmers in Grabag Sub District. Farmers with high formal education are more likely to implement the GAP than those with lowlevel education. It can be seen on t-value of Education which bigger than t-table for significance level $99.999 \%$ (5.516>1.667). The coefficient of education is 0.122 , and after the antilog is done, the result becomes 1.129 indicating that an increase in education score by 1 will bring an increase in score of GAP Implementation Level by 1.129 level score. The higher the education of farmer, the higher the possibility of farmer implementing GAP. It is because having higher education level will allow farmer to receive and adopt the new information more easily. The information received by farmers is generally obtained from training held by mills and fellow farmers. The result is compatible with the study carried out by Sriwichailamphan (2007) qouted by (Juarno et al., 2011) showing that educational level of farmers had a positive effect to adopt GAP.

\section{Non Significant Variable}

T-value of farmers' experience was -0.431 , which smaller than t-table $(-0.431<1.667)$. It means, the farmer's experience of shrimp cultivation do not affect the Implementation of GAP Level. The farmers in Grabag Sub District believe that their tradition is better than to the new technology offered to them. Farmers cultivated the shrimp 3 (three) times a year. Each period needs 3-4 months until the shrimp can be harvested.

Other variable such as age of farmers do not have significant effect on GAP implementation by the farmers statistically because the sig t value is bigger than 0.10 . Age does not affect vaname shrimp farmers in Grabag Sub District due to the varying age of farmers, yet still in productive age. Farmers' knowledge about GAP is not based on their age, however it is based on how farmers can open themselves to accept new technology and apply it. This result is in accordance with 
the research of (Suharni et al., 2017) stating that the age factor did not affect to the rate of technology adoption.

\section{The Effect of GAP Implementation to the Productivity}

Table 3. The Result of Analysis of GAP Implementation Affecting the Productivity

\begin{tabular}{lrrl}
\hline \multicolumn{1}{c}{ Variables } & Coefficient & \multicolumn{1}{c}{ Tstat } & Sig t \\
\hline C & 0.0001 & -1.532 & 0.130 \\
Ln LK & 0.325 & 2.735 & 0.008 \\
Ln Bnr & 0.233 & 1.794 & 0.077 \\
Ln Pkn & 0.424 & 5.328 & 0.000 \\
Ln Pro & 0.039 & 1.537 & 0.129 \\
Ln HKO & -0.034 & -0.578 & 0.565 \\
Ln PGAP & 0.597 & 1.468 & 0.147 \\
\hline R-squared & & 0.966 & \\
Adjusted & & 0.963 & \\
$\quad$ R-squared & & & \\
T-Table & & 1.668 & \\
\hline Source: Analysi &
\end{tabular}

Source: Analysis of Primary Data (2018)

\section{Significant Variables}

Pond area, shrimp seed, and feedvariable have an effect on productivity of pacific white shrimp in Grabag Sub District. T-value of pond area is 2.735 , which is bigger than t-table $(2.735>1.668)$. The coefficient of pond area is 0.325 , after antilog is applied, the result becomes 1.384 , meaning that an increase in pond area by $1 \mathrm{~m}^{2}$ will bring an increase in productivity by $1.384 \mathrm{~kg} / \mathrm{m}^{2}$. The result of research conducted by Andayani (2016) shows that pond area has a positive effect and significant to the productivity. Large pond will facilitate the shrimp movement and prevent cannibalism in shrimp due to high density.

The next variable affecting the productivity of pacific white shrimp in Grabag Sub District is shrimp seeds. T-value of shrimp seeds was 1.794 , which is bigger than t-table $(1.794>1.668)$. Shrimp seeds variable has odd ratio of 0.233 with positive regression coefficient, then after antilog is done, the result turns into 1.262 , meaning that the increase in shrimp seeds number by 1 percent will increase pacific white shrimp productivity by 1.262 percent, assuming that other factors were constant. The more seeds and height of stocking density will determine the level of technology and inputs needed in the cultivation system, so it will increase the shrimp productivity. This result is in line with the research of (Purnamasari et al., 2017). Based on the regulation of the Indonesian Ministry of Maritime Affairs and Fisheries number KEP.75/PERMEN KP/2016, stocking density of seeds shrimp is 30 seeds $/ \mathrm{m}^{2}$ until 100 seeds $/ \mathrm{m}^{2}$. In fact, the average of stocking density in Grabag Sub District is 100 seeds $/ \mathrm{m}^{2}$.

The last variable affecting the productivity of pacific white shrimp in Grabag Sub District is feed. The t-value of feed is 5.328, which is bigger than $\mathrm{t}$-table $(5.328>1.668)$. The increase in feed number by 1 percent would increase the pacific white shrimp productivity by 1.528 percent from the anti $\log$ of 0.424 , 
assuming that other factors are constant.

Feeding has to fulfill the nutritional needs for shrimp growth and adjust the eating habits and behavior of the shrimp. Feed has to fulfill the required quality and quantity, so that the shrimps grow well. The right amount in feeding will lead to the optimum growth of shrimp. Also, the waste can be controlled. The result of research conducted by Hidayatullah (2016) shows that feed has a positive effect and significant to the productivity. Farmers need to use Anco to know the appetite of shrimp. If the feed in Anco is empty, farmers should increase the amount of feed. They should check the Anco every 2 hours. The ideal of total amount of feed weight can be known by calculating the Food Convertion Ratio (FCR). The FCR is good between 1.2 to 1.5. The lower the FCR, the higher the weight gain obtained from the feed. In fact, farmers usually got a low FCR, which is 1 .

\section{Non Significant Variables}

Probiotic is not used by all farmers in Grabag Sub District. In fact, there are many farmers using chicken feces or other traditional ingredients to substitute probiotic. Probiotic does not affect the productivity of vaname shrimp, because it could increase the beneficial bacteria. If added a continuous dose, it will cause the shrimp to eat less feed.

The next variable having no significant effect is the labor. It indicated that no matter how many workers have been worked, it will not give any effect for the productivity of pacific white shrimp. Indeed, pacific white shrimp cultivation does not require many workers.

The last variable having no significant effect to productivity of pacific white shrimp in Grabag Sub District is GAP implementation. It implies that the implementation of GAP do not affect the productivity. However, it also do not contradict the productivity. It is because GAP focuses on environmentally friendly cultivation and produces high quality products.

\section{CONCLUSION AND SUGGESTION}

There are 4 (four) indicators of GAP with low score, which are chemical, biological, and fish medicine application, post-harvest handling, recording, and training. GAP implementation is significantly affected by the farmers' educational level.The productivity of pacific white shrimp is significantly affected by some factors, which are pond area, shrimp seeds, and feed. In order to produce good quality of pacific white shrimp, it will not contradict its productivity.

The government should participate by accompanying the farmers while doing pacific shrimp cultivation. It can be through training, counseling, etc. They should give understanding about GAP to the farmers as well, in order to produce good quality 
of pacific white shrimp and to perform environmentally friendly cultivation.

Farmers should keep applying the average of stocking density as 100 seeds/ $\mathrm{m}^{2}$ and increase the increase the FCR to 1.2. As GAP recommends the best average of stocking density around 30-100 seeds/ $\mathrm{m}^{2}$ and the FCR between 1.2-1.5. Farmers should use the fish medicine which is recommended by government instead of ginger or antidiarrheal medicines for human.

\section{REFERENCES}

Andayani, S. A. (2016). The Factors Affect Of Productivity And Income Freshwater Fish Rearing. Jurnal Ilmu Pertanian Dan Peternakan, 4(1), 206-213.

Andriyanto, F., Efani, A., \& Riniwati, H. (2013). Analisis Faktor-Faktor Produksi Usaha Pembesaran Udang Vanname (Litopenaeus vannamei) di Kecamatan Paciran Kabupaten Lamongan Jawa Timur ; Pendekatan Fungsi COBB-DOUGLASS. Jurnal ECSOFiM, 1(1), 82-96.

Arsad, S., Afandy, A., Purwadhi, A. P., V, B. M., Saputra, D. K., \& Buwono, N. R. (2017). Studi Kegiatan Budidaya Pembesaran Udang Vaname Dengan Pemeliharaan Berbeda. Jurnal Ilmiah Perikanan Dan Kelautan, 9(1), 1-14.
Hidayatullah, A. (2016). Analisis Faktor-

Faktor yang Mempengaruhi Produksi Usaha Keramba Ikan Mas di Kecamatan Babirik Kabupaten Hulu Sungai Utara. Jurnal Al Ulum Sains Dan Teknologi, 2(1), 14-19.

Juarno, O., Oktaviani, R., Fauzi, A., \& Nuryartono, N. (2011). Kinerja Produktivitas dan Faktor yang Berpengaruh Terhadap Total Factor Productivity (TFP) Tambak Udang Indonesia. Sosek KP, 6(2), 149-168.

Lestari, W., Hadi, S., \& Idris, N. (2009). Tingkat Adopsi Inovasi Peternak dalam Beternak Ayam Broiler di Kecamatan Bajubang Kabupaten Batang Hari. Jurnal Ilmiah Ilmu-Ilmu Peternakan Februari, XII(1), 14-22.

Purnamasari, F., Waluyati, L. R., \& Masyhuri. (2017). the Effect of Good Agriculture Practices (GAP) on Soybean Productivity With Cobb-Douglas Production Function Analysis in Kulon Progo Regency. Agro Ekonomi, 28(2), 220-236.

Sari, D. P., Syafruddin, R. F., \& Kadir, M. (2016). Penerapan Prinsip-Prinsip Good Agricultural Practice (GAP) Untuk Pertanian Berkelanjutan Di Kecamatan Tinggi Moncong Kabupaten Gowa. Jurnal Galung Tropika, 5(3), 151-163. 
Suharni, S., Waluyati, L. R., \& Jamhari, J. (2017). The Application Of Good Agriculture Practices (GAP) Of Shallot In Bantul Regency. Agro Ekonomi, 28(1), 48-63.

Sundari, R. S., \& Priyanto, Y. A. (2016). Efisiensi Penggunaan Faktor-Faktor Produksi Pada Teknologi Pendederan Ikan Lele (Clarias sp) Sangkuriang. Jurnal Teknologi Perikanan Dan Kelautan, 7(2), 200-207.

Suryani, S. (2016). Analisis Kelayakan Ekologi Budidaya Tambak Udang dalam Rangka Meningkatkan Ketahanan Pangan di Kabupaten Purworejo. Prosiding Seminar
Nasional Pertanian Peternakan Terpadu 1, 38, 378-389.

Triyatmo, B., Djumanto, Ustadi, \& Rustadi. (2016). Feasibility Study on the Profitability of Vannamei Shrimp Aquaculture on Coastal Area of Keburuhan Village, Purworejo Regency. Aquacultura Indonesiana, 17, 7-11.

Utomo, N. B., Istiyanti, E., \& Zulfanita. (2012). Analisis Usaha Budidaya Udang Vannamei (Litopenaues vannamei) di Desa Gedangan Kecamatan Purwodadi Kabupaten Purworejo. SURYA AGRITAMA, I, 85-93. 